\title{
Towards Effective Multidisciplinary Engineering Education: The Multidisciplinary Design Stream at Queen's University
}

\author{
David S. Strong \\ Professor and NSERC Chair in Design Engineering \\ Queen's University, Kingston, Ontario Canada K7L 3N6 strongd@post.queensu.ca
}

\begin{abstract}
Professional engineers in industry not only have to work frequently with those from other disciplines and professions, but often have to develop working skills and knowledge beyond their original discipline due to the requirements of their employment. Similarly, engineering design skills are also important attributes for professional engineers, particularly those working in product, process or system development. Surveys continue to suggest that industry perceives most engineering graduates, although technically competent, have minimal practical design skills, and lack the complimentary professional skills that are required for working successfully in the shared workplace.

In an effort to address the need for both multidisciplinary and design engineering skills, a multidisciplinary design stream is under development at Queen's University. Beginning with a course designed to develop a broad range of fundamental engineering design knowledge, professional skills and attitudes, the stream will continue to enhance the student's capability through a full year experience working on industry based design projects in multidisciplinary teams. The first elective offering of the design engineering fundamentals course attracted students from nine of ten disciplines. The project phase of the stream will be first offered in 2005-2006 to those students completing the fundamentals course. This paper will therefore discuss the multidisciplinary design stream as a work in progress.
\end{abstract}

\section{Introduction}

"The essence of engineering is design, a multidisciplinary approach to meeting economic, social and environmental needs [1]". This general statement has been echoed in many forms and by many authors. However, most North American engineering programs are still heavily science based, with true engineering design opportunities typically in the form of a final year capstone course. All too often, these are limited to a "paper design" without prototyping, testing, or iteration.

Engineering education literature has described the need for both improving engineering graduates' design skills, as well as much needed professional skills that round out a practicing engineer's "tool kit". Dym [2] suggests that the "modern, science based engineering curriculum" is viewed as originating with the Grinter report [3], which argued for more investment in science as a result of the scientific advances such as radar developed in World War II. Regardless of how this curriculum evolved, it has long since been recognized that this resulted in an imbalance of skills required for the practice of engineering in industry. Sound ability in engineering science and mathematics, while critical elements of any engineer's training, are only two of the core competencies required by practicing engineers.

As indicated by Todd et al [4], "it is sometimes forgotten that industry is an important customer of engineering education". The results of their survey of industry published in 1993 describe industrial perceptions of weaknesses in engineering graduates such as "technical arrogance... a desire for complicated and high-tech solutions...lack of design capability or creativity... all wanting to be analysts... a narrow view of engineering and related disciplines...weak communication skills...little skill or experience working in teams...being taught to work as individuals", amongst many others.

More recent industry surveys indicate that there may now be more alignment between industry and academe with respect to what topics are important. A 2002 publication by Eggert [5] surveyed both international industry and academic representatives, and had them rank perceived importance of topics and activities in undergraduate engineering education. These were then compared in terms of "supply (academe) and demand (industry)". Teamwork, engineering design specifications, and overall design 
process topics were ranked similarly. However there were noted gaps in specific design related skills such as creativity, project management, design for manufacture, and product testing. It was also reported that industry topics in highest "demand" were interdisciplinary design projects and industry based design projects.

Although there may be some improvement in alignment of learning priorities according to the Eggert survey, another 2002 survey by Frise et al [6] suggests that industry continues to be satisfied with graduate engineers' technical and scientific abilities, but have a "marked lack of satisfaction" with their non-technical capabilities and general knowledge of engineering practices. Design and "complementary" skills (communication, project management, economics, etc.) are again considered deficient.

The Canadian Engineering Accreditation Board (CEAB) [7] defines engineering design as follows: Engineering design integrates mathematics, basic sciences, engineering sciences and complementary studies in developing elements, systems and processes to meet specific needs. It is a creative, iterative and often open-ended process subject to constraints that may be governed by standards or legislation to varying degrees depending on the discipline. These constraints may relate to economic, health, safety, environmental, social or other pertinent interdisciplinary factors. Clearly, successful engineering design requires a broad cross-section of knowledge, skills, and attitudes. The NSERC Chairs in Design Engineering have listed and discussed this collection of knowledge, skills, and attitudes in order to achieve "design competency" [8].

Engineering Accreditation bodies have also recognized the need for design and multidisciplinary capabilities. The Accreditation Board for Engineering and Technology (ABET) [9] specifies that "an ability to design a system, component, or process to meet desired needs within realistic constraints..." and "an ability to function on multidisciplinary teams" are two of the eleven key elements which engineering programs must demonstrate are present in their new graduates.

This paper will discuss one approach to achieving design competence and multidisciplinary capabilities in the engineering program at Queen's University. This approach is called the Multidisciplinary Design Stream.

\section{Engineering Education at Queen's}

The Faculty of Applied Science at Queen's offers ten four-year programs in engineering, six of which are classical programs (Chemical, Civil, Computing, Electrical, Mechanical and Mining) and four of which are engineering science programs (Engineering Chemistry, Engineering Physics, Geological Engineering and Mathematics and Engineering). The first year class of approximately 600 students takes a common curriculum in year one and does not select from among the ten programs until the end of that year. The quality of students entering Queen's is very high and failure rates are correspondingly low. The Faculty has about 2500 students in the undergraduate engineering program.

Queen's is a residential university, and over 90\% of its students are in residence or in rented accommodation located within walking distance of the University. There is a long tradition of being on campus evenings and weekends, both for learning and for social activities.

More than a decade ago, Queen's began the evolution of an educational initiative that we refer to as Integrated Learning. Integrated Learning seeks to develop professional skills and to achieve deeper learning through an increased emphasis on how technical material relates to other ideas and subjects. It links material in one course to materials in other courses, links material in one engineering discipline to approaches and material in other engineering disciplines, and links engineering to business, environmental and social contexts. Moreover, it emphasizes how to elevate theory to practice.

A clearly defined priority that evolved from the Integrated Learning approach was the need for a new building to support and facilitate our objectives. Following an extensive planning and design effort with the involvement of all stakeholders, Beamish-Munro Hall, home of the Integrated Learning Centre (ILC), was opened in 2004 [10,11]. Combining 42 student "group rooms" (for team meetings), interactive and flexible teaching facilities, a design studio, prototyping centre, dedicated competitive student team facilities (for projects such as solar car and glider aircraft), first year studios, "live" building instrumentation, as well as housing the Engineering Society (student government) and faculty administration offices, the ILC has become an integrated "home" for engineering students at Queen's. Further details on this new facility can be found in the previous references.

In the common first year, Queen's engineering students take two unique courses that lay the foundation for design, multidisciplinary, and professional skills. APSC 100 "Practical Engineering Modules", first introduced in 1997, consists of three main elements: an introduction to communication, teamwork, and basic design methodology, as well as practical laboratory and analysis techniques; laboratory sessions wherein students are encouraged to design their own experiments; and an engineering design 
project in 4 person teams working on a variety of real engineering topics. The other course, APSC 190 "Professional Engineering Skills", first introduced in 2002, and extensively re-designed in 2004, endeavours to encourage students to "think like an engineer". Through group facilitation, case studies, and even role plays, students are introduced first hand to a broad variety of topics including societal and environmental issues, ethics, health, safety and liability, equity, learning techniques, and creative problem solving. Student teams then carry out a topical (and intentionally controversial) term design project that requires them to draw upon the elements discussed in the course material. Students are structured in "groups" of approximately 20, each of which are subdivided into 3 or 4 teams representing different roles as practicing engineers. These team and group structures encourage the development of communication, negotiation, time management, and team skills throughout the project.

In the second through fourth year of engineering studies, design content varies according to the choice of discipline, and multidisciplinary opportunities are very limited. In the second and third year, while some courses attribute fractions of course content as design and may assign design problems, very few actually teach supporting design methodology, tools, or techniques. Two exceptions to this are a second year "Design Techniques" course in Mechanical \& Materials Engineering (now entering its twelfth year) and a similar course in Civil Engineering, which was introduced last year. All disciplines incorporate a final year capstone design project and/or an independent research thesis. The majority of Mechanical \& Materials and Civil Engineering capstone projects are industry-based, with other disciplines opting mainly for faculty or student driven projects. All of the core capstone courses/projects are discipline-specific, although there is one elective multidisciplinary "industry project" course (not specifically design centred) that is offered through the Chemical Engineering department.

\section{The Multidisciplinary Design Stream}

In late 1999, the Natural Sciences and Engineering Research Council of Canada (NSERC) introduced a new program - the Chairs in Design Engineering/Chairs in Environmental Design Engineering Program (CDE/CEDE) [12]. On the basis that "design engineers are the enablers of innovation", one of the objectives of this program was to encourage education research and development, leading to the enhancement of design skills in Canadian engineering graduates. In preparing what became a successful application for design chair funding at Queen's, a significant review of existing engineering program was carried out. Consistent with industry surveys and current engineering education literature, it was determined that there were opportunities for improvement in engineering design and complimentary professional skills.

Although design in the engineering profession is inherently multidisciplinary, educational design experiences have traditionally been discipline specific. It was therefore determined that the best approach would be to provide an environment where student can learn and practice engineering design in a manner that best simulates the engineering workplace. Further, while our program at Queen's was providing design project opportunities in first year and in most capstone courses, it was noted that with only one exception, we were not substantively teaching the students the methodology or tools of engineering design. These were the driving elements for the creation of the Multidisciplinary Design Stream (MDS).

The initial offering of the MDS has been structured over three consecutive terms. In the first term, following successful completion of the first two years of engineering study, students from any discipline may elect to take the first MDS course, APSC 381 "Fundamentals of Design Engineering". In the second and third terms of the MDS, students in multidisciplinary teams carry out an industry-based project, covering all facets of engineering design from product definition through to physical or virtual prototyping, while continuing to receive occasional and timely relevant design instruction.

\section{MDS Design Fundamentals Course}

The objective of the first MDS "fundamentals" course is to provide the student with a sound background in engineering design methodology, tools, and techniques, consistent with industry practice. The pilot offering of this course was in term 2 of the past academic year (Jan-April 2005). Elective enrollment consisted of 33 students representing 9 of the 10 engineering disciplines at Queen's, plus 1 student from Arts and Science (Economics). Twenty-five students were in third year, and the remaining 8 were in the fourth and final year of their engineering program, with the exception of several doing a fifth year in the "dual degree" program.

Much of the course material, both instructional and practical, was drawn directly from the instructor's experience from more that two decades in industry. Course topics included:

- Design process methodology

- Client statements and problem identification 
- Carrying out a needs analysis

- Gathering user and market information

- Literature searching

- Functional analysis

- Searching and interpreting patents

- Creativity methods for idea generation

- Idea selection techniques

- Team skills

- Consulting

- Reliability and quality

- Hazard assessment

- Design for " $\mathrm{x}$ "

- Engineering economics/cost estimation

- Project management techniques

- Risk analysis

- Regulatory and Safety considerations

- Detailed design techniques

- Developing test plans

- Assessing technical and economic feasibility

- Social and environmental considerations

- Presentation skills

- Report writing skills

The material was all presented and utilized in the context of engineering design, and included many supporting tools and techniques. The course was offered in a 3 hour evening class, once per week, in order to avoid scheduling conflicts. This structure was also preferred in order to provide more time for students to get involved with material and exercises. The teaching style was very interactive, with short lectures interspaced with exercises that immediately involved the students in applying the material just discussed.

Students were also required to carry out a term length design project. Selecting from a list of carefully chosen projects, students listed their top three projects choices and were then formed into multidisciplinary teams based on the student's preference. Nominal team size was 4 persons, but numbers of students and their choice of project necessitated two 3 person teams. (It is interesting to note that 25 of the 33 students received their first project choice.)

Initially, specific exercises were created to support the lecture material. However, as the projects got underway, the in-class application exercises were applied directly to the student projects. Following brief exercise periods, students were encouraged to present and discuss their thoughts on the application of the technique, thus illustrating variable interpretations of the process. Students submitted weekly status reports related to both team and project progress. Just past the mid-point of the course, students made formal project presentations and submitted a detailed interim report, formatted as a professional engineering report. The presentations and reports were assessed, and student teams received formative detailed feedback on design methodology, techniques, and on their presentation and report writing skills. At the end of term, final project presentations were made to the class and invited guests, and final reports were then submitted.

In an effort to further augment the students' experience, part of one class was devoted to consulting on design process with students from another elective engineering class. Student teams in the other class were engaged in projects related to recycling technologies. Paired in team to team meetings, after a tentative beginning, students had extensive discussions, sharing both technical and design process information. All parties reported positive results.

Both formal and anecdotal feedback on the fundamentals course was extremely positive. In addition to the standard university course feedback form, students participated in entry and exit surveys designed to self-assess knowledge, skills, and attitudes related to engineering design. All data indicated that students believed they were much more prepared to cope with engineering design problems at the end of the course. Several final year students indicated that they would have liked to have taken the course before they had done their capstone project or thesis. All comments received with regard to the multidisciplinary teams and projects were very favorable. Another interesting comment from several students was that, based on their understanding of engineering design by the end of the course, they thought their self rating of understanding engineering design at the outset of the course was much too high. One can only assume that such individual reflection is a positive indication that students have grasped the reality of, and need for a broad understanding of engineering design.

\section{MDS Project}

In the fall of 2005, the MDS will continue with the first offering of APSC 480 "Multidisciplinary Design Project". Reinforcing the belief that students can significantly benefit from learning the process, tools, and techniques of engineering design prior to taking on a major capstone design project, the pre-requisite for this project course is successful completion of APSC 381 , the previously described design fundamentals course.

In the fall term, students will choose their top 3 preferences from a selection of industry based design projects. Students will be grouped into multidisciplinary teams and paired with faculty supervisors and industry mentors. Using many of the 
skills developed in the fundamentals course, teams will work through the design process while adapting to the realities of an industry project. In addition to applying sound technical skills, this will require a focus on project management, effective communication, appropriate economic considerations, and serious consideration of social, environmental, safety, and regulatory factors. Project teams will submit weekly progress reports to both faculty and industry supervisors, meet weekly with faculty, and communicate regularly with their client sponsor either in person or via conference call, depending on the client's location. At the end of the first term, students will present their proposed design in both formal presentations and in written engineering reports.

In the second term, projects will enter an iterative prototype/test/design review phase. Weekly status updates and regular communication with supervisors will continue. Wherever possible, student teams will be encouraged to make use of both rapid and traditional prototyping facilities available in the new Integrated Learning Centre at Queen's. Final formal presentations will be made to the industry clients and a team of faculty representing the various disciplines of students involved in the projects.

\section{Challenges}

Introducing the multidisciplinary design stream has not been without challenges. Although engineering education literature has widely reported a perceived need for more design and multidisciplinary skills, programs continue to be heavily loaded with core science based courses. Hence, for students in most disciplines, the third year of the engineering program leaves little room for additional electives, and the question of opting out of one science course in order to add one in design is not typically well accepted.

Scheduling of multidisciplinary courses is also a challenge. Difficulty in finding three hours in the normal daily course slots without conflict for students from all ten engineering disciplines led to the evening offering. Although relatively uncommon in the engineering program at Queen's, the evening scheduling seemed to be well accepted by the students. From an instructor's point of view, it also allowed flexibility in duration of class activities and worked well to accommodate guest speakers.

Acceptance of the multidisciplinary design project as an acceptable alternative to discipline-based capstone courses is currently under consideration. Some departments have indicated they will allow students to opt out of their disciplinary capstone course, while others appear less inclined to do so. Indicative of their support, many students have indicated in their exit survey that they will enroll in the multidisciplinary project course in addition to their departmental capstone, if necessary.

\section{Summary Comments}

The pilot offering of the first course in the multidisciplinary design stream has demonstrated that students from various engineering disciplines can harmoniously learn design methodology, tools, and techniques, and apply them effectively in a multidisciplinary engineering design project. Based on the university's standard course evaluation and on entrance/exit surveys, student satisfaction is high and demand is expected to grow. The exit survey also indicated extensive interest amongst the students in continuing with the project phase of the MDS, although some indicated that it will depend on their ability to opt out of their departmental capstone.

Several engineering departments have expressed interest in the first "fundamentals" course as a core offering. Already, some of the course material has been shared to support other disciplinary courses, particularly at the second year level. With the current challenges in developing multidisciplinary offerings in the second and third years of the program, incorporating elements of engineering design into existing courses is encouraged. In addition to offering a design specialization for students so inclined, the ultimate goal is to enhance the design capability of every engineering student.

\section{Acknowledgements}

I would like to recognize the Natural Sciences and Research Council of Canada for funding provided through the Chairs in Design Engineering (CDE) program. I would also like to thank Elizabeth May, whose contributions as both a research assistant and teaching assistant have been very helpful in the introduction of the multidisciplinary design stream.

\section{References}

[1] Canadian Academy of Engineering, "The Evolution of Engineering Education in Canada", Canadian Academy of Engineering, Ottawa, December 1999.

[2] Dym, C.L.; Agogino, A.M.; Eris, O; Frey, D.D.; Leifer, L.J., "Engineering Design Thinking, Teaching, and Learning", Journal of Engineering Education, Vol. 94, No. 1, January 2005, pp. 103-120.

[3] Grinter, L.E., "Report of the Committee on Evaluation of Engineering Education", Journal of Engineering Education, Vol.46, No. 1, pp.25-60.

[4] Todd, R.H.; Sorensen, C.D.; Magleby, S.P., "Designing a Senior Capstone Course to Satisfy Industrial 
Customers", Journal of Engineering Education, Vol. 82, No. 2, April 1993, pp. 92-100.

[5] Eggert, R.J., "Engineering Design Education: Surveys of Demand and Supply", 2003 ASEE Annual Conference \& Exposition: Staying in Tune with Engineering Education, American Society for Engineering Education, Nashville, TN, United States, June 2003, pp.1901-1912.

[6] Frise, P.R.; Sirizzotti, M.D.; Gaspar, R.G.; Reader, G.T., "Mechanical Engineering Skills Needs in Canadian Industry", Annual Conference of the Canadian Society of Mechanical Engineers, Queen's University, Kingston, Ontario, May 2002.

[7] Canadian Engineering Accreditation Board (Canadian Council of Professional Engineers), "2004 Accreditation Criteria and Procedures" http://www.ccpe.ca/e/files/report_ceab.pdf

[8] NSERC Chairs in Design Engineering, "The Engineering Design Competency", The Inaugural CDEN Design Conference, Montreal, Quebec, July 2004.

[9] ABET, "2005-2006 Criteria for Accrediting Engineering Programs", www.abet.org

[10] McCowan, J.D.; Mason, J.L., "Creating a facility for developing professional skills", ASEE Annual Conference Proceedings, 2002 ASEE Annual Conference and Exposition: Vive L'ingenieur, American Society for Engineering Education, Montreal, Quebec, Canada, Jun 16-19 2002, p 10627- 10633.

[11] Strong, D.S.; McCowan, J.D., "Effective Workspace for Engineering Education: The Integrated Learning Centre at Queen's University in Kingston", in Proc. $2^{\text {nd }}$ Annual CDEN Design Conference, Kananaskis, Alberta, July 2005.

[12] NSERC Chairs in Design Engineering Program, http://www.nserc.gc.ca/professors e.asp?nav=profnav\& $\underline{\mathrm{lbi}=\mathrm{c} 3}$ 